Jorge González Bastías

\title{
En la vera rústica
}

IVIR en la montaña, mirar el turbio río con sus corrientes bravas. Sentir ante el re-

[manso

acogedor la blanda caricia del Estio que adormece el ensueño y que lleva al descanso.

Sentir ardiente sed de la naturaleza, sed del árbol y el agua, de la espiga y del viento; y estar siempre anhelante de esa noble tristeza en que hay ansia de dicha y ansia de sufrimiento.

¿Qué diría el arroyo que me vió tantas horas mirando tristemente el correr de sus aguas? ¿Pensaría que acaso me embelesaba el blando rumor de su corriente musical y nostálgica?

¿Qué dirian la roca de la margen y el árbol que acogieron piadosos mis extrañas vägancias? ¿Qué dirían los pájaros de mi silencio, signo de esta inquietud sin vida y esta angustia sin lágrimas? 